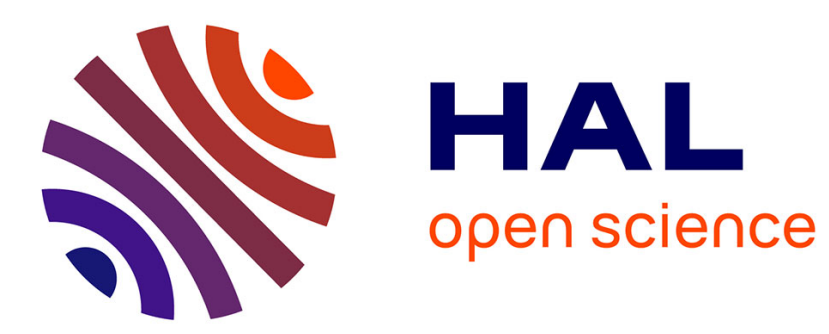

\title{
5-HT4 receptors: History, molecular pharmacology and brain functions
}

Joël Bockaert, Sylvie Claeysen, Valerie Compan, Aline Dumuis

\section{To cite this version:}

Joël Bockaert, Sylvie Claeysen, Valerie Compan, Aline Dumuis. 5-HT4 receptors: History, molecular pharmacology and brain functions. Neuropharmacology, 2008, 55 (6), pp.922-931. 10.1016/j.neuropharm.2008.05.013 . hal-01667629

\section{HAL Id: hal-01667629 \\ https://hal.science/hal-01667629}

Submitted on 20 Feb 2020

HAL is a multi-disciplinary open access archive for the deposit and dissemination of scientific research documents, whether they are published or not. The documents may come from teaching and research institutions in France or abroad, or from public or private research centers.
L'archive ouverte pluridisciplinaire $\mathbf{H A L}$, est destinée au dépôt et à la diffusion de documents scientifiques de niveau recherche, publiés ou non, émanant des établissements d'enseignement et de recherche français ou étrangers, des laboratoires publics ou privés. 


\title{
5-HT 4 receptors: History, molecular pharmacology and brain functions
}

Joël Bockaert ${ }^{\mathrm{a}, \mathrm{b}, \mathrm{c},{ }^{*}, \text { Sylvie Claeysen }}{ }^{\mathrm{a}, \mathrm{b}, \mathrm{c}}$, Valérie Compan ${ }^{\mathrm{a}, \mathrm{b}, \mathrm{c}}$, Aline Dumuis ${ }^{\mathrm{a}, \mathrm{b}, \mathrm{c}}$

${ }^{\text {a }}$ CNRS UMR 5203, Institut de Génomique Fonctionnelle, Montpellier, France

${ }^{\mathrm{b}}$ INSERM U661, Montpellier, France

${ }^{\mathrm{c}}$ Université Montpellier, Montpellier, France

* Corresponding author. CNRS UMR 5203, Institut de Génomique Fonctionnelle, 141 rue de la Cardonille, 34094 Montpellier Cedex 5, France. Tel.: +33 467142930; fax: +33 467542432.

E-mail address: joel.bockaert@igf.cnrs.fr.

Keywords: Serotonin 5-HT4 receptor; Memory Feeding; Mood Depression

\begin{abstract}
Twenty years ago, we started the characterization of a 5-HT receptor coupled to cAMP production in neurons. This receptor obviously had a different pharmacology to the other 5-HT receptors described at that time, i.e. the $5-\mathrm{HT}_{1}, 5-\mathrm{HT}_{2}, 5-\mathrm{HT}_{3}$ receptors. We proposed to name it the 5- $\mathrm{HT}_{4}$ receptor. Nowadays, $5-\mathrm{HT}_{4}$ receptors are one of the most studied GPCRs belonging to the "rhodopsin" family. Thanks to the existence of a great variety of ligands with inverse agonist, partial agonist, agonist and antagonist profiles, the pharmacological and physiological properties of this receptor are beginning to emerge. Although some 5- $\mathrm{HT}_{4}$ partial agonists have been on the market for gastro-intestinal pathologies, $5-\mathrm{HT}_{4}$ receptor drugs have still to be commercialized for brain disorders. However, since 5- $\mathrm{HT}_{4}$ receptors have recognized effects on memory, depression and feeding in animal models, there is still hope for a therapeutic destiny of this interesting target in brain disorders.
\end{abstract}




\section{Introduction}

In July 1990, at the Second IUPHAR satellite meeting on Serotonin, held by the Serotonin Club in Basel, Switzerland, began a series of "Serotonin Club Irvine H. Page Lectures". S.J. Peroutka, a wellknown and appreciated expert in the serotonin field gave a tribute to Dr. Irvine H. Page (Peroutka, 1991). S.J. Peroutka reminded younger colleagues that 5-hydroxytryptamine (5-HT) was successively called "vasotonin" (1933 - Bayliss and Ogden), "Enteramine" (1933 - Vialle and Erspamer), but that the modern name "serotonin" can be dated to Dr. Page's Science paper in 1948 (Rapport et al., 1948).

In 1985, Irvine H. Page wrote "A long life has taught me that the natural history of one's active participation in a discovery is about 5-10 years. Then the subject grows complicated, new young faces appear with their better methods and they take over" (Page, 1985).

Thus, I was very honoured when I received the Serotonin Club's invitation to give the Irvine H. Page Lecture, especially since we discovered the 5-HT 4 receptors $\left(5-\mathrm{HT}_{4} \mathrm{Rs}\right)$ (Dumuis et al.,1988a) 20 years ago with A. Dumuis and are still working on them, using, we hope, effective methods. The aim of this paper is to review 20 years of research on $5-\mathrm{HT}_{4} \mathrm{Rs}$.

\section{The pre-history of $5-\mathrm{HT}_{4} \mathrm{Rs}$}

My interest in neurotransmitter sensitive adenylate cyclase began more than 40 years ago when I came back to the Collège de France in Paris after post-doctoral training at Northwestern University in Chicago, where I was already working on G-protein coupled receptor desensitization. Paul Greengard had just published a paper on a dopamine sensitive adenylate cyclase in striatal membranes (Kebabian et al., 1972). The possibility of using cAMP production, following receptor activation, to discover new neurotransmitter receptors and analyse their pharmacology, brain distribution and regulation was fascinating. I decided to interact with my new neighbouring neuroscientists and fantastic colleagues $\mathrm{J}$. Glowinski and M. Hamon. In 1978, with M. Hamon, we described a post-synaptic 5-HT sensitive adenylate cyclase in different brain areas of rat and guinea-pig brain (Enjalbert et al., 1978) (Fig. 1A). Of course, due to a lack of specific drugs, we were unable to pharmacologically characterize the receptors involved.

When I moved to Montpellier in 1982, I decided to use primary cultures of neurons and glial cells to follow up my work on neurotransmitter receptors coupled to second messengers (cAMP, IP3, $\mathrm{Ca}^{2+}$, etc.). This was a very productive period since we discovered the metabotropic glutamate receptors in striatal neurons (Sladeczek et al., 1985) and 5-HT ${ }_{4} \mathrm{Rs}$ in colliculi neurons (Fig. 1B) (Dumuis et al., 1988a). 


\section{History}

3.1. From the "Naughty but nice period" (Clarke et al., 1989) to "A place in the sun" period (Bockaert et al., 1992)

In the 1980s, thanks to binding techniques, the molecular classification of 5-HT receptors took a definitive pathway. Three receptor classes were recognized at that time, the $5-\mathrm{HT}_{1}$, the $5-\mathrm{HT}_{2}$ and the 5-HT 3 (Bradley et al., 1986). We decided that it was timely to characterize the 5-HT receptors positively coupled to an adenylate cyclase in primary cultures of colliculi neurons. We immediately noticed that the receptor involved was insensitive to 5- $\mathrm{HT}_{1}$ and 5- $\mathrm{HT}_{2}$ antagonists (Fig. 1C see also Dumuis et al., 1988a) and that the only active antagonist was a 5-HT 3 antagonist (Tropisetron: ICS 205930) although with an $\mathrm{IC}_{50}$ being incompatible with a 5- $\mathrm{HT}_{3}$ receptor interaction (Fig. 1C). Interestingly, 5carboxamidotryptamine (5-CT) was 50 times less potent than 5-HT (Fig. 1B). This incited us to replicate (Fig. 1D) the work of Shenker et al. (1987) who described, in guinea-pig hippocampal membranes, two 5-HT sensitive adenylate cyclases. One stimulated with high potency by 5-CT, 5-HT (and 8-OH-DAPT) that was identified at that time as "5- $\mathrm{HT}_{1 \mathrm{~A}}$ receptor"-mediated (we now know that a $5-\mathrm{HT}_{7}$ receptor was involved) and the other stimulated with lower potency by 5-HT and 5-CT (Fig. 1D). We found that this latter was inhibited, like the 5-HT-sensitive adenylate cyclase of colliculi neurons, by high concentrations of Tropisetron but not by a specific 5-HT 3 antagonist MDL 72222 (Dumuis et al.,1988b) (Fig.1E). We concluded, in the 1988 Molecular Pharmacology paper (Dumuis et al., 1988a) that until further classification of the 5-HT receptors is available, we propose to associate these receptors (in colliculi neurons and guinea-pig hippocampal membranes) with a novel category of receptors: the $5-\mathrm{HT}_{4}$.

In 1989, at the International Symposium on "Serotonin from cell biology to pharmacology and therapeutics" in Firenze, we presented these results that were received with scepticism by the serotonin nomenclature committee. Benzamides, such as metoclopramide, renzapride, cisapride and zacopride were rapidly recognized as potent agonists (Bockaert et al.,1990). This was important because this formed a link between the 5-HT receptor coupled to adenylate cyclase and an unclassified prokinetic 5-HT receptor in guinea-pig ileum, insensitive to classical 5- $\mathrm{HT}_{1-3}$ antagonists, stimulated by benzamides and blocked by high concentrations of Tropisetron (Clarke and Bockaert, 1993). This was "nice" (a new 5-HT receptor expressed both in brain and gastro-intestinal organs was likely to exist), but "naughty" because we named it 5- $\mathrm{HT}_{4}$ without permission. Very rapidly, new specific antagonists were discovered, such as the benzamide SDZ 205557 and the benzimidazolone DAU 6215. The use of functional assays associated with the availability of these new drugs led to the characterization of the new 5- $\mathrm{HT}_{4}$ receptor in rat oesophagus, guinea-pig colon, human and pig atrium and adrenocortical cells. The 5-HT 4 receptors earned a "place in the sun" in 1992 (Bockaert et al., 1992). 


\subsection{Pharmacology and molecular biology periods (1990-2002)}

From 1990 onwards, most pharmaceutical companies and some academic groups synthesized a wide series of 5-HT 4 agonists and antagonists (for reviews see Bockaert et al., 2004, 1997). Among the agonists, the first class includes substituted tryptamines as well as indole carbazimidamides (including maleate tegaserod "Zelnorm") which is prescribed for women suffering from irritable bowel syndromes with constipation, but recently withdrawn from the market because of possible cardio-vascular problems. The second class includes a long series of 2-methoxy-4-amino-5-chloro benzamides, such as metoclopramide, zacopride and cisapride. The latter has been on the market for gastro-oesophageal diseases and is still used with certain restrictions in some countries. A benzodioxane derivative the SL65.0155 is particularly potent for learning and memory (Moser et al., 2002) and has reached phase IIb for Alzheimer's disease. The third class includes the benzimidazolones, such as BIMU8 and the fourth aryl ketones which has a compound, RS 67333 with a large alkyl group, known to easily cross the blood brain barrier. Another interesting agonist is a pyridine carboxamide, a very recently described procognitive drug (VRX-03011) that is in phase II for Alzheimer's disease. Among the antagonists, GR 113808 was the first 5- $\mathrm{HT}_{4} \mathrm{R}$ antagonist with a low affinity for 5- $\mathrm{HT}_{3} \mathrm{R}$ and was used under a tritiated form $\left[{ }^{3} \mathrm{H}\right]$ GR 113808 for binding studies. Antagonist classes include benzoates (such as SDZ 205557), benzoate dioxane (such as SB 204070 and SB 207710) in which the 5-chloro has been substituted for a radioactive iodine ${ }^{125} \mathrm{I}$, an excellent ligand for binding studies [ $\left.{ }^{125} \mathrm{I}\right] \mathrm{SB} 207710$, benzimidazolones (DAU 6285) and aryl ketones. Finally, with Roche Laboratories, we found very potent inverse agonists (RO 116-0086 and RO 116-1148) which are des-amino, des-chloro benzoate dioxanes (Joubert et al., 2002). Using either form $\left[{ }^{3} \mathrm{H}\right] \mathrm{GR} 113808$ and $\left[{ }^{125} \mathrm{I}\right] \mathrm{SB} 207710$ brain distribution has been studied (for a review see Bockaert and Dumuis, 1997). The receptor is localized on neurons, the highest densities being in olfactory bulb, islands of Calleja, basal ganglia and accumbens, hippocampus, substantia nigra. Within the nigro-striatal pathway the receptor is localized both in cell bodies and terminals of GABA neurons. In the cortex, the hippocampus and the amygdala, 5- $\mathrm{HT}_{4} \mathrm{Rs}$ are likely localized on cholinergic neurons $\left(5-\mathrm{HT}_{4} \mathrm{Rs}\right.$ stimulate acetylcholine release) but also on glutamatergic neurons (Bockaert et al., 2004; Bockaert and Dumuis, 1997; Huang and Kandel, 2007).

The 5-HT 4 R gene is the longest among the GPCR genes $(700 \mathrm{~kb})$ and consists of 38 exons (Bockaert et al., 1997). Its 5' non-translated region is exceptionally long ( $>500 \mathrm{~kb})$ and complex. The coding sequence includes at least 14 exons. To date, 10 functional splice variants have been described. For 9 of them, splicing gives rise to alternate C-terminal domains after a single position (L358) named $\mathrm{a}, \mathrm{b}, \mathrm{c}$. One splice variant (h) is generated in the second extracellular loop. As some (such as h or i) do not present any frame stop codons, additional combinations probably remain to be discovered (Bockaert et al., 2006b). 


\section{G protein-dependent and -independent signalling and interacting proteins}

\subsection{G protein dependent}

Since $5-\mathrm{HT}_{4} \mathrm{Rs}$ were discovered following their capacity to activate adenylate cyclase, the 5-HT ${ }_{4} \mathrm{R}$-mediated Gs/cAMP/PKA signalling pathway is evidently the best studied (Fig. 2). In transfected cell lines, several other couplings have been found (see Bockaert et al., 2006b) including coupling to $\mathrm{G}_{\mathrm{q}}$ and $\mathrm{G}_{13}$. However, such couplings have not yet been found in native cells. Following PKA activation, a series of ionic currents are modulated. These include a long-lasting inhibition of $\mathrm{K}^{+}$ currents (mediated by a PKA-dependent inhibition of phosphatases) which generates neuronal excitability and a decrease in spike accommodation (Ansanay et al., 1995; Bockaert et al., 2006b). cAMP produced by 5 - $\mathrm{HT}_{4} \mathrm{Rs}$ also activates the exchange factor Epac which activates $\alpha$-secretase and the release of sAPP $\alpha$ (soluble amyloid precursor protein) via an Epac/Rap1/Ras pathway (Lezoualc'h and Robert, 2003).

\subsection{G protein-independent}

In cell lines as well as in colliculi neurons in culture, 5- $\mathrm{HT}_{4} \mathrm{Rs}$ activated the extracellular signalregulated kinase (ERK) (Barthet et al., 2007; Mohler et al., 2007; Restivo et al., 2007). Curiously, we recently found that this activation was mostly Gs/cAMP/PKA-independent. Using pharmacological, genetic and molecular tools, we also demonstrated that the classical $G$ proteins $\left(G_{q}, G_{i}, G_{o}\right)$ and associated downstream messengers were not involved. In contrast, the 5- $\mathrm{HT}_{4} \mathrm{R}$-mediated ERK activation was dependent on Src tyrosine kinase and interestingly not dependent on b-arrestin which is found to mediate many G protein-independent ERK activations by GPCRs (Barthet et al., 2007). We found that a $5-\mathrm{HT}_{4} \mathrm{R} / \mathrm{Src}$ complex was formed which persisted upon endocytosis (Barthet et al., 2005). The 5-HT ${ }_{4} \mathrm{R}$-mediated ERK stimulation may be important for 5-HT $\mathrm{H}_{4} \mathrm{R}$-mediated long-term potentiation (LTP) (Bockaert et al., 2006b; Huang and Kandel, 2007). The 5-HT 4 R-dependent, cAMP/PKAindependent, activation of Src has also been found in intestinal cell lines (CaCo-2 and T84) 5-HT $\mathrm{Rs}_{4}$ (Gill et al., 2005). In these cells, Src seems to activate a PLC/Ca ${ }^{2+} /$ calmodulin pathway and finally controls the $\mathrm{Na}^{+} / \mathrm{H}^{+}$exchanger (Gill et al., 2005).

\subsection{Associated proteins}

Although some differences in signal transduction between the C-termini splice variants have been reported, this was found exclusively in cell lines but not in native cells. The physiological relevance, if any, of the splice variants remains to be elucidated (Bockaert et al., 2006b). In an effort to make some progress in the possible different signalling of $5-\mathrm{HT}_{4} \mathrm{R}$ splice variants, we used a fishing and 
proteomic approach to define the composition of the "receptosome" associated with the C-termini of three 5-HT $\mathrm{H}_{4} \mathrm{R}$ splice variants (Joubert et al., 2004) Two of them, 5-HT 4 a, and 5- $\mathrm{HT}_{4 \mathrm{e}}$ express a canonical recognition motif for PDZ domains at their C-termini. SCF, the C-terminal of 5-HT4a may interact with class I PDZ domains, whereas VPV, the C-terminal of 5- $\mathrm{HT}_{4 \mathrm{e}}$ may interact with class II PDZ domains. The 5-HT $\mathrm{Hb}_{4 \mathrm{~b}} \mathrm{C}$-terminal (-SDT) shows no consensus interaction motif. Ten proteins have been found to interact with 5-HT ${ }_{4 a} \mathrm{Rs}$. Among them, seven encompass one or several PDZ domains (Bockaert et al., 2006a; Joubert et al., 2004). The two more interesting ones were (i) SNX27 (sortin nexin 27) that belongs to the huge nexin family implicated in the regulation of membrane protein trafficking and (ii) NHERF $\left(\mathrm{Na}^{+} / \mathrm{H}^{+}\right.$exchanger regulatory factor). In fact, two splicing forms of SNX27 (a and $b$, also called Mrt1a and Mrtb) interact with 5-HT $\mathrm{H}_{4}$ and are localized in early endosomes. SNX27a is constitutively expressed, whereas SNX27b is induced by methamphetamine treatment (Kajii et al., 2003). NHERF interacts with the FERM domain of activated ezrin. In fibroblast cells expressing NHERF and 5-HT 4 Rs, ezrin was redistributed from the cytoplasm to microvilli and was co-localized with NHERF and 5-HT $\mathrm{Rs}_{4}$ (Joubert et al., 2004).

\section{Mechanisms of 5-HT4R desensitization}

Many years ago, we described in colliculi neurons (Ansanay et al., 1992) and rat oesophagus (Ronde et al., 1995) that 5-HT ${ }_{4}$ Rs rapidly desensitized (more than $60 \%$ in $5 \mathrm{~min}$ ). The desensitization (uncoupling) was homologous and not reproduced by cAMP. We recently decided to further analyse the mechanisms involved (Barthet et al., 2005). However, in HEK 293 and COS-7 cells transfected with 5 -HT ${ }_{4} \mathrm{Rs}$, we found that no significant uncoupling of the receptor occurred upon stimulation (Barthet et al.,2005). We found that this was due to the low concentration of theGRK2 in HEK293 andCOS-7 cells, a GPCR kinase which is highly expressed in neurons and brain. Co-transfection of HEK 293 or COS-7 cells with GRK2 was sufficient to reproduce the rapid and profound 5- $\mathrm{HT}_{4} \mathrm{R}$ uncoupling (Barthet et al., 2005). In contrast, the endocytosis of $5-\mathrm{HT}_{4} \mathrm{R}$ which is a phenomenon dissociated from uncoupling required only "low concentrations" of GRK2 found in HEK 293 and COS-7 cells. The uncoupling and endocytosis were independent and dependent on GRK2 kinase activity, respectively. Thus, phosphorylation of a Ser/Thr cluster, in the C-terminal, and common to all splice variants was required for endocytosis but not for uncoupling. Endocytosis of 5- $\mathrm{HT}_{4} \mathrm{Rs}$ required both $\beta$-arrestin and dynamin. We found no difference in uncoupling and endocytosis among the different $5-\mathrm{HT}_{4} \mathrm{R}$ splice variants.

We recently found (manuscript in preparation) that desensitization of the G-protein-independent 5-HT ${ }_{4} \mathrm{R}$-stimulated Src kinase activation required GRK5 instead of GRK2. 


\section{From constitutive activity $(\mathrm{CA})$ to receptor activation}

The molecular mechanism by which agonists, antagonists and inverse agonists activate and inactivate GPCRs is a key question in pharmacology. 5- $\mathrm{HT}_{4} \mathrm{Rs}$ are particularly interesting for such studies because of the long series of compounds of different chemical classes which are available.

Another interesting and almost unique property of 5-HT ${ }_{4} \mathrm{Rs}$ is their high CA (Claeysen et al., 1999; Bockaert et al., 2005).

Compared to $\beta_{2}$-adrenergic receptors $\left(\beta_{2}\right.$-ARs), all C-termini splice variants of $5-\mathrm{HT}_{4} \mathrm{R}$ have a very high CA (Fig. 3A). The shorter is the $\mathrm{C}$-terminal, the higher is the CA. Thus, the C-terminal is a key regulator of the CA. Truncation of the C-terminus further increases the CA. The C-termini of $5-\mathrm{HT}_{4} \mathrm{Rs}$ are key element of activation, but certainly not the only one. Comparison of the crystal structures of inactive rhodopsin (bound by the inverse agonist cis-retinal) and partially active rhodopsin (metarhodopsin I) (Ruprecht et al., 2004), as well as site-directed mutagenesis of histamine H1 associated with molecular modelling (Jongejan et al., 2005), proposed that activation of GPCRs includes the disruption of a hydrogen bond between two well-conserved residues W6.48 and D2.50. This disruption triggers the conformational transition of N7.49 towards D2.50 and ultimately, leads to the disruption of the "ionic lock" between R3.50 and D/E3.49 as well as with additional D/E 6.30 (Fig. 3C). The W6.48 which is in the gauche ${ }^{+}\left(\mathrm{g}^{+}\right)$rotamer pointing toTM 7 (TM $=$ transmembrane $)$ in the inactive state is submitted to a "toggle switch" and is in the trans $(t)$ rotamer conformation pointing to TM5 in the activated state. Studies on histamine H1 (Jongejan et al., 2005) and 5-HT 4 Rs (manuscript in preparation) indicate that $\mathrm{T} 3.36$ is also submitted to a "concerted toggle switch" with W6.48. Interestingly, among the amine receptors, only very few receptors have a Threonine at position 3.36 (1\%), all other 5-HT receptors have a Ser or a Cys at that 3.36 location. $\beta_{2}$-AR has an alanine (Fig. 3B), which may account for the low basal activity of this receptor.

We found that binding of 5-HT and other indole-amine derivatives was totally dependent on the ionic interaction between the protonated amine of the side chain and the aspartate (A) at position 3.32 (D.32). In contrast, binding and activation of benzamides, such as S-zacopride, and benzimidazolones, such as BIMU8, did not depend on the presence of D3.32. Thus, the D3.32A mutant was the first RASSL (receptor activated solely by synthetic ligands) coupled to $\mathrm{G}_{\mathrm{s}}$ (Claeysen et al., 2003). Interestingly, some neutral or weak partial agonists were almost full agonists on the RASSL. Site-directed mutagenesis and molecular modelling, performed in collaboration with L. Pardo (manuscript in preparation), indicate that the BIMU8 agonist triggers the concerted toggle switch of T3.36 and W6.48 by forming a hydrogen bond with W6.48, whereas the benzamides induced this concerted switch by forming a hydrogen bond with T.3.36. 


\section{Brain functions}

Although 5- $\mathrm{HT}_{4} \mathrm{Rs}$ control many important functions at the periphery, including those of the gastro-intestinal and urinary tracts, human heart and adrenal gland, we will focus this review on three brain functions which are emerging and could be relevant in therapy: memory and cognition, mood, behaviour and feeding.

\subsection{Learning and memory}

A great number of studies indicate pro-cognitive effects of 5- $\mathrm{HT}_{4} \mathrm{R}$ agonists both on short-term memory (such as social olfactory memory) (Fig. 4A) or long-term olfactory memory (such as olfactory associative memory) (Fig. 4B) (for a review see Bockaert et al., 2004). Increase in memory acquisition also includes auto-shaping task, object recognition, Morris water-maze task when the inter-trial intervals were high $(2 \mathrm{~h})$, delayed matching performance and impeded spontaneous alteration scores. In addition, 5 - $\mathrm{HT}_{4} \mathrm{R}$ activation reduces deficit in memory induced by atropine, scopolamine and 5 - $\mathrm{HT}_{4} \mathrm{R}$ antagonists (for a review see Bockaert et al., 2004).

The cellular basis of such learning and memory effects may be an increase in acetylcholine release found in frontal cortex and hippocampus and an increase in LTP which has been described in hippocampus and amygdala (Bockaert et al., 2004; Huang and Kandel, 2007). Moreover, other recent reports further support this notion that $5-\mathrm{HT}_{4} \mathrm{Rs}$ play a role in memory. They reported an association between 5-HT $\mathrm{H}_{4} \mathrm{R}$ mRA and protein expression in cortical areas, hippocampus, olfactory tubercles on one hand and memory consolidation on the other hand (Pérez-García et al., 2006; Manuel-Apolinar et al., 2005).

In addition to these effects on learning and memory, an effect of $5-\mathrm{HT}_{4} \mathrm{Rs}$ on non-amyloidogenic metabolism pathway of APP via stimulation of the $\alpha$-secretase has been described (Lezoualc'h and Robert, 2003; Cachard-Chastel et al., 2007). In correlation with the precedent data, a recent report by Cho and $\mathrm{Hu}$ (2007) demonstrated that a selective 5-HT4 partial agonist, RS 67333, inhibits the generation of the $\beta$-amyloid peptide $(\mathrm{A} \beta)$ in primary cortical neurons.

Interestingly, two 5- $\mathrm{HT}_{4} \mathrm{R}$ partial agonists, the SL 65.0155 from Sanofi-Aventis (Moser et al., 2002) and VRX-03011 (Epix Pharmaceuticals; Mohler et al., 2007) which have high pro-mnesic properties in rodents have reached clinical phase II for the treatment of Alzheimer's disease. Both compounds act synergically with cholinesterase inhibitors on rodent memory. All these data are in perfect correlation with previous reports showing that there is indeed a marked loss of $5-\mathrm{HT}_{4} \mathrm{R}$ binding sites in cortical and hippocampal regions in the Alzheimer brain (Reynolds et al., 1995; Wong et al., 1996).

Finally, we have recently found, in collaboration with French and Italian colleagues, that SL65.0155 enhances simultaneously olfactory discrimination performance and associated spine growth an effect blocked by the RS 39604 antagonist (Fig. 4B). SL65.0155 has no effect alone (Restivo et al., 
2007). Spine growth and density have been found to be associated with LTP induction and are considered to be a possible cellular basis of memory formation (for a review see Alvarez and Sabatini, 2007). It is also tempting to make a link between 5-HT $\mathrm{H}_{4} \mathrm{R}$-induced cAMP formation and spine density. Indeed, cAMP reduces phosphorylation of cyclin-dependent kinase 5 (cdk5) site in the Wiskott-Aldrich syndrome protein (Wave1) and increases spine density in a Wave1-dependent manner (Kim et al., 2006).

\subsection{Control of mood, putative antidepressant role of in $5-H T_{4} R$ agonists}

All antidepressant treatments and especially serotonin reuptake inhibitors (SSRIs) increase the efficacy of 5-HT transmission at the post-synaptic levels and finally induce post-synaptic 5-HT receptors activation. Unfortunately, the initial elevation of 5-HT concentration triggered by SSRIs induces the stimulation of 5-HT $\mathrm{HT}_{1 \mathrm{~A}}$ receptors localized on cell bodies of 5-HT neurons in the raphe, inhibiting their firing and counteracting the facilitation of 5-HT transmission (Fig. 5A). Thus, the 3-6 weeks delay before the onset of the therapeutic action of the antidepressant corresponds to the time needed for 5-HT $\mathrm{H}_{1 \mathrm{~A}}$ receptor desensitization. Compounds that directly and rapidly stimulate the firing activity of 5-HT neurons are expected to be swiftly acting antidepressants. In fact, $5-\mathrm{HT}_{4} \mathrm{R}$ agonists have been found to exert positive tonic and phasic effects on the firing of a sub-population of 5-HT neuron of the dorsal raphe nucleus (DRN) when injected at the periphery but not directly at the raphe level (Lucas et al., 2005; Lucas and Debonnel, 2002; Conductier et al., 2006). This suggests that the effect was mediated by $5-\mathrm{HT}_{4} \mathrm{Rs}$ localized elsewhere. Note also that $5-\mathrm{HT}_{4} \mathrm{R}$ knock-out mice have reduced spontaneous activity of 5-HT dorsal neurons. Injection of the herpes simplex virus (HSV) coding for $5-\mathrm{HT}_{4} \mathrm{Rs}$ increased DRN 5-HT neuronal mean activity when injected in the medial pre-frontal cortex (mPFC) but not in the striatum or hippocampus (Lucas et al., 2005) (Fig. 5B). Thus, 5- $\mathrm{HT}_{4} \mathrm{Rs}$ of the mPFC, probably localized on some pyramidal neurons known to innervate the DRN, exert a tonic and phasic stimulatory action on DRN which surprisingly did not seem to desensitize (Fig. 5A). Thus, as expected citalopram, a SSRI, was far more potent in inhibiting DRN firing in 5- $\mathrm{HT}_{4} \mathrm{R}$ knock-out mice than in WT mice (Conductier et al., 2006).

Recently, the group of G. Debonnel investigated the possibility that RS 67333 and prucalopride, two 5-HT $\mathrm{H}_{4} \mathrm{R}$ agonists, could have antidepressant activity. They found that acute injection of both drugs, like citalopram, reduced the immobility time in the forced-swimming test, and that the inhibition of 5HT neuron firing rate, by citalopram, was shifted to the right by RS 67333 (Fig. 5C, D). In addition, after 3 days of injection of RS 67333, an increase in 5-HT release in CA3 neurons of hippocampus, measured by the enhancement of post-synaptic $5-\mathrm{HT}_{1 \mathrm{~A}} \mathrm{R}$ activity, was observed. A 3-day treatment with RS 67333 significantly enhanced the mitogenesis in the sub-granular zone (SGZ) of the hippocampus, an effect also associated with long-term (3-6 weeks) SSRI treatment. A 3-day period of treatment with citalopram was insufficient to produce such an effect. Altogether, these findings illustrate that $5-\mathrm{HT}_{4} \mathrm{R}$ agonists could be considered to be a putative class of antidepressants. 


\subsection{Feeding behavior}

Looking for a phenotype associated with invalidation of $5-\mathrm{HT}_{4} \mathrm{Rs}$ in mice, we first found that the absence of this receptor attenuated stress-induced hypophagia and novelty-induced exploratory activity (Compan et al., 2004). This suggests that 5- $\mathrm{HT}_{4} \mathrm{Rs}$ may be involved in stress-induced anorexia. Following this idea and the observation that $5-\mathrm{HT}_{4} \mathrm{Rs}$ are highly expressed in nucleus accumbens (NAc), we recently found that direct stimulation of $5-\mathrm{HT}_{4} \mathrm{Rs}$ in the NAc reduced the physiological drive to eat and increased CART (cocaine- and amphetamine-regulated transcript) mRNA content in fed and fooddeprived WT but not knock-out mice (Fig. 6A-C). CART is an anorectic peptide. 5-HT ${ }_{4}$ Rs control CART mRNA expression via a cAMP/PKA signalling pathway. We also found, using WT and knockout mice, that the anorectic effect of 3,4-N-methylene-dioxymethamphetamine (MDMA; the active principle of ecstasy) involves 5-HT 4 Rs (Fig. 6D). Finally, we found that the 5-HT 4 Rs and MDMAinduced anorexia were both reduced by injecting CART siRNA into the NAc (Fig. 6E). Collectively, these results demonstrate that the $5-\mathrm{HT}_{4} \mathrm{R}$-mediated up-regulation of CART in the NAc triggers the appetite-suppressant effects of ecstasy.

\section{Conclusion}

Twenty years after their first description, $5-\mathrm{HT}_{4} \mathrm{Rs}$ still have some mysteries to be discovered and safe $5-\mathrm{HT}_{4} \mathrm{R}$ drugs for clinical use are still to be developed. Among the mysteries, we can quote:

(1) The incredible length of the gene and the number of splice variants. Why is there such a diversity? (2) The high constitutive activity of 5-HT4Rs. Are 5-HT4Rs constitutively active in some neurons or neuronal compartments? If so, what roles do they play? Does an endogenous inverse agonist effectively exist?

The clinical use of 5-HT $\mathrm{H}_{4} \mathrm{R}$ drugs has encountered some difficulties. Some drugs like cisapride or maleate tegaserod have been on the market for gastro-oesophageal reflux, constipation or irritable bowel syndromes, but were removed from the market because of their adverse cardiac problems, probably unrelated to their action on $5-\mathrm{HT}_{4} \mathrm{Rs}$. The tentative to use of $5-\mathrm{HT}_{4} \mathrm{R}$ partial agonists for cognitive deficiencies particularly, but not exclusively, in Alzheimer's disease is still ongoing. The use of $5-\mathrm{HT}_{4} \mathrm{R}$ ligands in feeding disorders (bulimia or anorexia) but also in depression is still an ongoing continual challenge. Finally, 5-HT4 Rs constitute an excellent "model" of GPCR for molecular pharmacology studies. This is due to the great number of agonists, antagonists and inverse agonists of diverse chemical structures available, the generation of mutants, including a very simple and potent RASSL which may be used in gene therapy and the possibility of obtaining mg amounts of pure, native and functional 5- $\mathrm{HT}_{4} \mathrm{R}$ proteins (Baneres et al., 2005). 


\section{References}

Alvarez, V.A., Sabatini, B.L., 2007. Anatomical and physiological plasticity of dendritic spines. Annu. Rev. Neurosci. 30, 79-97.

Ansanay, H., Dumuis, A., Sebben, M., Bockaert, J., Fagni, L., 1995. A cyclic AMPdependent, longlasting inhibition of a K. current in mammalian neurons. Proc. Natl. Acad. Sci. U. S. A. 92, 6635-6639.

Ansanay, H., Sebben, M., Bockaert, J., Dumuis, A., 1992. Characterization of homologous 5-HT4 receptor desensitization in colliculi neurons. Mol. Pharmacol. 42, 808-816.

Baneres, J.L., Mesnier, D., Martin, A., Joubert, L., Dumuis, A., Bockaert, J., 2005. Molecular characterization of a purified 5-HT4 receptor: a structural basis for drug efficacy. J. Biol. Chem. 280, 20253-20260.

Barthet, G., Framery, B., Gaven, F., Pellissier, L., Reiter, E., Claeysen, S., Bockaert, J., Dumuis, A., 2007. 5-hydroxytryptamine 4 receptor activation of the extracellular signal-regulated kinase pathway depends on Src activation but not on G protein or beta-arrestin signaling. Mol. Biol. Cell 18, 1979-1991.

Barthet, G., Gaven, F., Framery, B., Shinjo, K., Nakamura, T., Claeysen, S., Bockaert, J., Dumuis, A., 2005. Uncoupling and endocytosis of 5-HT4 receptors: distinct molecular events with different GRK2 requirements. J. Biol. Chem. 280, 27924- 27934.

Bockaert, J., Be' camel, C., Joubert, L., Gavarini, S., Dumuis, A., Marin, P., 2006a. In: Roth, B. (Ed.), Identification of 5-HT2 and 5-HT4 Receptor-interacting Proteins. Humana Press, Totowa, New Jersey.

Bockaert, J., Claeysen, S., Becamel, C., Dumuis, A., Marin, P., 2006b. Neuronal 5-HT metabotropic receptors: fine-tuning of their structure, signaling, and roles in synaptic modulation. Cell Tissue Res. 326, 553-572.

Bockaert, J., Claeysen, S., Compan, V., Dumuis, A., 2004. 5-HT4 receptors. Curr. Drug Targets CNS Neurol. Disord. 3, 39-51.

Bockaert, J., Claeysen, S., Joubert, 1., Fagni, L., Dumuis, A., 2005. Molecular and cellular determinants of GPCR splice variant constitutive activity. In: Mannhold, R., Kubinyi, H., Folkers, G. (Eds.), Methods and Principles in Medicinal Chemistry. Wiley-VCH, Weinheim, pp. 43-54.

Bockaert, J., Dumuis, A., 1997. Localization of 5-HT4 receptors in vertebrate brain and their potential behavioral roles. In: Bioscience, L. (Ed.), 5-HT4 Receptor in the Brain and Periphery, pp. 6386. Austin, TX, USA.

Bockaert, J., Fagni, L., Dumuis, A., 1997. 5-HT4 receptors: an update. In: Baumgarten, H.G., Go“" thert, M. (Eds.), Handbook of Experimental Pharmacology: Serotoninergic Neurons and 5-HT Receptors in the CNS. Springer-Verlag, Berlin, Heidelberg, New York, pp. 439-465.

Bockaert, J., Fozard, J., Dumuis, A., Clarke, D., 1992. The 5-HT4 receptor: a place in the sun. Trends Pharmacol. Sci. 13, 141-145.

Bockaert, J., Sebben, M., Dumuis, A., 1990. Pharmacological characterization of 5hydroxytryptamine4 (5-HT4) receptors positively coupled to adenylate cyclase in adult guinea pig hippocampal membranes: effect of substituted benzamide derivatives. Mol. Pharmacol. 37, 408-411.

Bradley, P.B., Engel, G., Feniuk, W., Fozard, J.R., Humphrey, P.P.A., Middlemiss, D.N., Myelcharane, E.J., Richardson, B.P., Saxena, P.R., 1986. Proposals for the classification and nomenclature of functional receptors for 5-hydroxytryptamine. Neuropharmacology 25, 563-576.

Cachard-Chastel, M., Lezoualc'h, F., Dewachter, I., Delome' nie, C., Croes, S., Devijver, H., Langlois, M., Van Leuven, F., Sicsic, S., Gardier, A.M., 2007. 5-HT 4 receptor agonists increase sAPPalpha levels in the cortex and hippocampus of male C57BL/6j mice. Br. J. Pharmacol. 150 (7), 883-892.

Cho, S., Hu, Y., 2007. Activation of 5-HT4 receptors inhibits secretion of beta-amyloid peptides and increases neuronal survival. Exp. Neurol. 203 (1), 274-278.

Claeysen, S., Joubert, L., Sebben, M., Bockaert, J., Dumuis, A., 2003. A single mutation in the 5-HT4 receptor (5-HT4-R D100(3.32)A) generates a Gs-coupled receptor activated exclusively by synthetic ligands (RASSL). J. Biol. Chem. 278, 699-702. 
Claeysen, S., Sebben, M., Becamel, C., Bockaert, J., Dumuis, A., 1999. Novel brainspecific 5-HT4 receptor splice variants show marked constitutive activity: role of the C-terminal intracellular domain. Mol. Pharmacol. 55, 910-920.

Clarke, D.E., Bockaert, J., 1993. 5-HT4 receptor: an overview. In: Vanhoutte, P.M., Saxena, P.R., Paoletti, R., Brunello, N., Jackson, A. (Eds.), Serotonin from Cell Biology to Pharmacology and Therapeutics. Klu"wer Academic Publishers.

Clarke, D.E., Craig, D.A., Fozard, J.R., 1989. The 5-HT4 receptor: naughty but nice. Trends Pharmacol. Sci. $10,385-386$.

Compan, V., Zhou, M., Grailhe, R., Gazzara, R.A., Martin, R., Gingrich, J., Dumuis, A., Brunner, D., Bockaert, J., Hen, R., 2004. Attenuated response to stress and novelty and hypersensitivity to seizures in 5-HT4 receptor knock-out mice. J. Neurosci. 24, 412-419.

Conductier, G., Dusticier, N., Lucas, G., Cote, F., Debonnel, G., Daszuta, A., Dumuis, A., Nieoullon, A., Hen, R., Bockaert, J., Compan, V., 2006. Adaptive changes in serotonin neurons of the raphe nuclei in 5-HT(4) receptor knock-out mouse. Eur. J. Neurosci. 24, 1053-1062.

Dumuis, A., Bouhelal, R., Sebben, M., Cory, R., Bockaert, J., 1988a. A nonclassical 5hydroxytryptamine receptor positively coupled with adenylate cyclase in the central nervous system. Mol. Pharmacol. 34, 880-887.

Dumuis, A., Sebben, M., Bockaert, J., 1988b. Pharmacology of 5-hydroxytryptamine1A receptors which inhibit cAMP production in hippocampal and cortical neurons in primary culture. Mol. Pharmacol. 33, 178-186.

Enjalbert, A., Bourgoin, S., Hamon, M., Adrien, J., Bockaert, J., 1978. Post-synaptic serotonin-sensitive adenylate cyclase in the central nervous system. I. Development and distribution of serotonin and dopamine-sensitive adenylate cyclases in rat and guinea-pig. Mol. Pharmacol. 14, 2-10.

Gill, R.K., Saksena, S., Tyagi, S., Alrefai, W.A., Malakooti, J., Sarwar, Z., Turner, J.R., Ramaswamy, K., Dudeja, P.K., 2005. Serotonin inhibits Nap/Hp exchange activity via 5-HT4 receptors and activation of PKC alpha in human intestinal epithelial cells. Gastroenterology 128, 962-974.

Huang, Y.Y., Kandel, E.R., 2007. 5-Hydroxytryptamine induces a protein kinase A/ mitogen-activated protein kinase-mediated and macromolecular synthesisdependent late phase of long-term potentiation in the amygdala. J. Neurosci. 27, 3111-3119.

Jean, A., Conductier, G., Manrique, C., Bouras, C., Berta, P., Hen, R., Charnay, Y., Bockaert, J., Compan, V., 2007. Anorexia induced by activation of serotonin 5-HT4 receptors is mediated by increases in CART in the nucleus accumbens. Proc. Natl. Acad. Sci. U. S. A. 104, 16335-16340.

Jongejan, A., Bruysters, M., Ballesteros, J.A., Haaksma, E., Bakker, R.A., Pardo, L., Leurs, R., 2005. Linking agonist binding to histamine $\mathrm{H} 1$ receptor activation. Nat. Chem. Biol. 1, 98-103.

Joubert, L., Claeysen, S., Sebben, M., Bessis, A.S., Clark, R.D., Martin, R.S., Bockaert, J., Dumuis, A., 2002. A 5-HT4 receptor transmembrane network implicated in the activity of inverse agonists but not agonists. J. Biol. Chem. 277, 25502-25511.

Joubert, L., Hanson, B., Barthet, G., Sebben, M., Claeysen, S., Hong, W., Marin, P., Dumuis, A., Bockaert, J., 2004. New sorting nexin (SNX27) and NHERF specifically interact with the 5HT4a receptor splice variant: roles in receptor targeting. J. Cell Sci. 117, 5367-5379.

Kajii, Y., Muraoka, S., Hiraoka, S., Fujiyama, K., Umino, A., Nishikawa, T., 2003. A developmentally regulated and psychostimulant-inducible novel rat gene mrtl encoding PDZ-PX proteins isolated in the neocortex. Mol. Psychiatry 8, 434-444.

Kebabian, J.W., Petzold, G.L., Greengard, P., 1972. Dopamine-sensitive adenylate cyclase in caudate nucleus of rat brain, and its similarity to the "dopamine receptor". Proc. Natl. Acad. Sci. U. S. A. 69, 2145-2149.

Kim, Y., Sung, J.Y., Ceglia, I., Lee, K.W., Ahn, J.H., Halford, J.M., Kim, A.M., Kwak, S.P., Park, J.B., Ho Ryu, S., Schenck, A., Bardoni, B., Scott, J.D., Nairn, A.C., Greengard, P., 2006. Phosphorylation of WAVE1 regulates actin polymerization and dendritic spine morphology. Nature 442 (7104), 814-817.

Letty, S., Child, R., Dumuis, A., Pantaloni, A., Bockaert, J., Rondouin, G., 1997. 5-HT4 receptors improve social olfactory memory in the rat. Neuropharmacology 36, 681-687.

Lezoualc'h, F., Robert, S.J., 2003. The serotonin 5-HT4 receptor and the amyloid precursor protein processing. Exp. Gerontol. 38, 159-166. 
Lucas, G., Compan, V., Charnay, Y., Neve, R.L., Nestler, E.J., Bockaert, J., Barrot, M., Debonnel, G., 2005. Frontocortical 5-HT4 receptors exert positive feedback on serotonergic activity: viral transfections, subacute and chronic treatments with 5-HT4 agonists. Biol. Psychiatry 57, 918925.

Lucas, G., Debonnel, G., 2002. 5-HT4 receptors exert a frequency-related facilitatory control on dorsal raphe nucleus 5-HT neuronal activity. Eur. J. Neurosci. 16, 817-822.

Lucas, G., Rymar, V.V., Du, J., Mnie-Filali, O., Bisgaard, C., Manta, S., Lambas-Senas, L., Wiborg, O., Haddjeri, N., Pineyro, G., Sadikot, A.F., Debonnel, G., 2007.

Serotonin(4) (5-HT(4)) receptor agonists are putative antidepressants with a rapid onset of action. Neuron 55, 712-725.

Manuel-Apolinar, L., Rocha, L., Pascoe, D., Castillo, E., Castillo, C., Meneses, A., 2005. Modifications of 5-HT4 receptor expression in rat brain during memory consolidation. Brain Res. 1042 (1), $73-81$.

Marchetti-Gauthier, E., Roman, F.S., Dumuis, A., Bockaert, J., Soumireu-Mourat, B., 1997. BIMU1 increases associative memory in rats by activating $5-\mathrm{HT}_{4}$ receptors. Neuropharmacology 36 , 697-706.

Mohler, E.G., Shacham, S., Noiman, S., Lezoualc'h, F., Robert, S., Gastineau, M., Rutkowski, J., Marantz, Y., Dumuis, A., Bockaert, J., Gold, P.E., Ragozzino, M.E., 2007. VRX-03011, a novel 5-HT4 agonist, enhances memory and hippocampal acetylcholine efflux. Neuropharmacology 53, 563-573.

Moser, P.C., Bergis, O.E., Jegham, S., Lochead, A., Duconseille, E., Terranova, J.P., Caille, D., BerqueBestel, I., Lezoualc'h, F., Fischmeister, R., Dumuis, A., Bockaert, J., George, P., Soubrie, P., Scatton, B., 2002. SL65.0155, a novel 5-hydroxytryptamine( 4) receptor partial agonist with potent cognition-enhancing properties. J. Pharmacol. Exp. Ther. 302, 731-741.

Page, I.H., 1985. The Neonatology of Serotonin. Raven Press, New York. Pérez-García, G., GonzalezEspinosa, C., Meneses, A., 2006. An mRNA expression analysis of stimulation and blockade of 5-HT7 receptors during memory consolidation. Behav. Brain Res. 169 (1), 83-92.

Peroutka, S.J., 1991. A Tribute to Dr. Irvine H. Page. Birkha"user Verlag, Basel. Rapport, M.M., Green, A.A., Page, I.H., 1948. Serum vasoconstrictor (serotonin): isolation and characterization. J. Biol. Chem. 176, 1243-1251.

Restivo, L., Roman, F., Dumuis, A., Bockaert, J., Marchetti, E., Ammassari-Teule, M., December 12, 2007. The promnesic effect of G-protein-coupled 5-HT(4) receptors activation is mediated by a potentiation of learning-induced spine growth in the mouse hippocampus. Neuropsychopharmacology, doi:10.1038/sj. npp.1301644.

Reynolds, G.P., Mason, S.L., Meldrum, A., De Keczer, S., Parnes, H., Eglen, R.M., Wong, E.H., 1995. 5-Hydroxytryptamine (5-HT)4 receptors in post mortem human brain tissue: distribution, pharmacology and effects of neurodegenerative diseases. Br. J. Pharmacol. 114 (5), 993-998.

Ronde, P., Ansanay, H., Dumuis, A., Miller, R., Bockaert, J., 1995. Homologous desensitization of 5hydroxytryptamine4 receptors in rat esophagus: functional and second messenger studies. J. Pharmacol. Exp. Ther. 272, 977-983.

Ruprecht, J.J., Mielke, T., Vogel, R., Villa, C., Schertler, G.F., 2004. Electron crystallography reveals the structure of metarhodopsin I. EMBO J. 23, 3609-3620.

Shenker, A., Maayani, S., Weinstein, H., Green, J.P., 1987. Pharmacological characterization of two 5hydroxytryptamine receptors coupled to adenylate cyclase in guinea pig hippocampal membranes. Mol. Pharmacol. 31, 357-367.

Sladeczek, F., Pin, J.-P., Re' casens, M., Bockaert, J., Weiss, S., 1985. Glutamate stimulates inositol phosphate formation in striatal neurones. Nature 317, 717-719.

Wong, E.H., Reynolds, G.P., Bonhaus, D.W., Hsu, S., Eglen, R.M., 1996. Characterization of $\left[{ }^{3}\right.$ H]GR113808 binding to 5-HT4 receptors in brain tissues from patients with neurodegenerative disorders. Behav. Brain Res. 73 (1-2), 249-252. 


\section{Figure legends}

\section{Figure 1}

Some historical experiments which have characterized a neuronal 5-HT receptor coupled to adenylate cyclase as new 5-HT receptors that we called 5-HT 4 Rs. (A) Dose-response curves for 5-HT sensitive adenylate cyclase in colliculi homogenates. Modified from Enjalbert et al. (1978). (B) Effects of various concentrations of 5-HT and 5-CT (5-carboxamidotryptamine) on cAMP production in colliculi neurons in primary cultures. Modified from Dumuis et al. (1988a). (C) Effect of a series of 5-HT antagonists on the 5-HT-stimulated cAMP production in colliculi neurons in primary cultures. The 5-HT concentration was $1 \mathrm{mM}$. Modified from Dumuis et al. (1988a). (D) Stimulation of adenylate cyclase activity of adult guinea-pig hippocampal membranes by 5-HT and 5-CT. Modified from Dumuis et al. (1988a). (E) Inhibition of 5-CT-stimulated adenylate cyclase activity in adult guinea-pig hippocampal membranes by Tropisetron at two 5-CT concentrations: 0.3 and $100 \mathrm{mM}$. Modified from Dumuis et al. (1988a).

\section{Figure 2}

A general schema of $\mathrm{G}_{\mathrm{s}}$-dependent and $\mathrm{G}_{\mathrm{s}}$-independent signalling and desensitization of 5- $\mathrm{HT}_{4} \mathrm{Rs}$.

\section{Figure 3}

Constitutive activity and activation of 5-HT 4 Rs. (A) Mouse 5- $\mathrm{HT}_{4} \mathrm{R}$ (m5-HT 4 Rs) splice variants exhibited high but also different constitutive activities. Comparison with the constitutive activity of human $\beta_{2}$-adrenergic receptors $\left(\beta_{2}\right)$. Modified from Claeysen et al. (1999). (B) Nature of the residue at position 3.36 in amine receptors. The high constitutive activity of 5- $\mathrm{HT}_{4} \mathrm{Rs}$ may be due to the presence of a $\mathrm{T}$ at this position (Jongejan et al., 2005). (C) Proposed hydrogen bond network linking D2.50W6.48 through two water molecules in the inactive conformation of rhodopsin. This link is disturbed during activation. Modified from Jongejan et al. (2005).

\section{Figure 4}

5-HT 4 Rs and memory. (A) Role of 5- $\mathrm{HT}_{4} \mathrm{Rs}$ in social memory. Social recognition of juvenile conspecifics by adult rat during $5 \mathrm{~min}$ (first exploration period $(\mathrm{P} 1)$ ) and at a delay of $30(\mathrm{P} 2=30)$ and $120(\mathrm{P} 2=120) \mathrm{min}$. At the $30 \mathrm{~min}$ delay between $\mathrm{P} 1$ and P2, adults recognized the juvenile as indicated by a reduction of the exploration period $(\mathrm{P} 2 / \mathrm{P} 1<1)$, whereas after a $120 \mathrm{~min}$ delay, all adults have lost their memory of juveniles. The recognition of juveniles was individual-specific, a different juvenile was recognized as a new individual after $30 \mathrm{~min}(\mathrm{P} 2 / \mathrm{P} 1=1)$. BIMU1 $(10 \mathrm{mg} / \mathrm{kg})$ injected after the first presentation enhanced short-term memory (i.e. recognition of the identical but not the different juvenile after a 2-h delay). Modified from Letty et al. (1997). (B) Involvement of 5-HT 4 Rs in olfactory memory. In this task, rats deprived of water for $48 \mathrm{~h}$ were trained to make two odor-reward associations. One arbitrarily odor is designed as positive ( $\mathrm{S}+$ ) and the other as negative (S-). Rats had to approach the odor 
and water only when the odor was positive. Approach to the negative odor resulted in presentation of non-adversive light and water was not delivered. Individual trials were presented in a quasi-random fashion. Mean performance obtained across the five sessions of 60 trials by rats injected with BIMU1 $(10 \mathrm{mg} / \mathrm{kg}$ ) or saline (control) after the session 3 are indicated. In the reversal session, rats were tested 1 month after the injection of BIMU1 or saline (control) with reversal of the valence of the previous learned odors. Rats injected with BIMU1 are less efficient than naive rats in learning this reverse test likely because they still "remember" the previous odor association. Modified from Marchetti-Gauthier et al. (1997). (C) Mice were trained to discriminate between two odors as in B. In the "trained" group the positive odor was associated with the reward (water) in 100\% of the trials. In the "pseudo-trained group there was no positive odor as each odor was randomly associated with the reward on $50 \%$ of the trials". Golgi-Cox impregnated oblique dendrites of CA1 pyramidal neurons are shown. Statistical analysis (Restivo et al., 2007) indicates that the spine density was not different between control and pseudo-trained mice, whereas there was a difference between pseudo-trained and trained, between trained plus saline and trained plus SL65.0155. Modified from Restivo et al. (2007).

\section{Figure 5}

5-HT ${ }_{4} \mathrm{Rs}$ and depression. (A) Localisation of 5-HT receptors controlling activity of 5-HT dorsal raphe nucleus (DRN). 5- $\mathrm{HT}_{1 \mathrm{~A}} \mathrm{Rs}$ are on cell bodies of 5-HT neurons whereas 5- $\mathrm{HT}_{4} \mathrm{Rs}$ are not. We hypothesized that 5- $\mathrm{HT}_{4} \mathrm{Rs}$ which stimulate the activity of 5-HT neurons are localized in the medial prefrontal cortex (mPFC) (see Lucas et al., 2005). (B) Mean firing rate of DRN. Control: integrated firing rate histogram showing a sample of DRN in sham-operated rat. Herpes simplex virus (HSV) HSV$5-\mathrm{HT}_{4} \mathrm{Rs}$ in mPFC: integrated firing rate histogram showing a sample of DRN in rats injected with coding 5- $\mathrm{HT}_{4} \mathrm{Rs}$, in mPFC. The effect of various injections of the virus in the $\mathrm{mPFC}$, striatum (Str), hippocampus (Hip) and with a virus coding Lac-Z in the mPFC. Modified from Lucas et al. (2005). (C) Effect of citalopram, a SSRI (10 mg/kg), and two 5 - $\mathrm{HT}_{4} \mathrm{Rs}$ agonists, prucalopride $(2.5 \mathrm{mg} / \mathrm{kg})$ and RS $67333(1.5 \mathrm{mg} / \mathrm{kg})$ on the time spent immobile in the forced-swimming test. Modified from Lucas et al. (2007). (D) A 3-day treatment period with RS 67333 reduced the inhibition of 5-HT neuron firing induced by citalopram, via 5-HT $\mathrm{HA}_{1 \mathrm{~A}}$ receptor activation. Modified from Lucas et al. (2007).

\section{Figure 6}

5-HT ${ }_{4}$ Rs and feeding (modified from Jean et al., 2007). (A) Coronal midbrain section showing the nucleus accumbens (NAc) in which drugs and siRNA were injected. A schematic signalling pathway showing the central role of 5-HT ${ }_{4} \mathrm{Rs}$ in MDMA (3,4-methylene-dioxymethamphetamine) (and likely cocaine) in inhibition of feeding via a cAMP/PKA synthesis of CART. (B) Direct injection of the 5 -HT ${ }_{4} \mathrm{R}$ agonist BIMU8 in NAc inhibited food intake in food-deprived mice. The same injection stimulated CART synthesis. Food intake was measured between 1 and $3 \mathrm{~h}$ after treatment. (C) An i.p. injection of MDMA increased CART mRNA content in NAc of WT but not in 5-HT $\mathrm{H}_{4}$ knock-out mice. 
(D) In food-deprived mice, the i.p. injection of MDMA decreased food intake of WT but not 5-HT $\mathrm{H}_{4}$ knock-out mice. Food intake was measured for $3 \mathrm{~h}$ following the treatment. (E) The anorectic effects of BIMU8 and MDMA were reduced when CART was knocked down in the NAc using siCART. Food intake was measured for $1 \mathrm{~h}$ after treatment. 
A

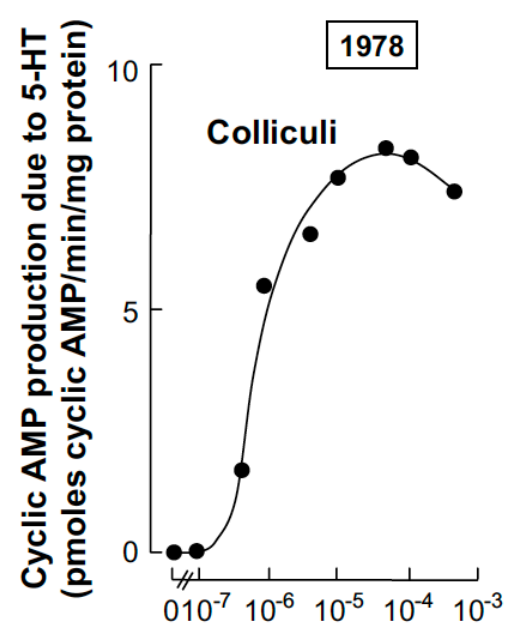

From Enjalbert et al (1978) Molecular Pharmacology

C

Colliculi neurons in culture

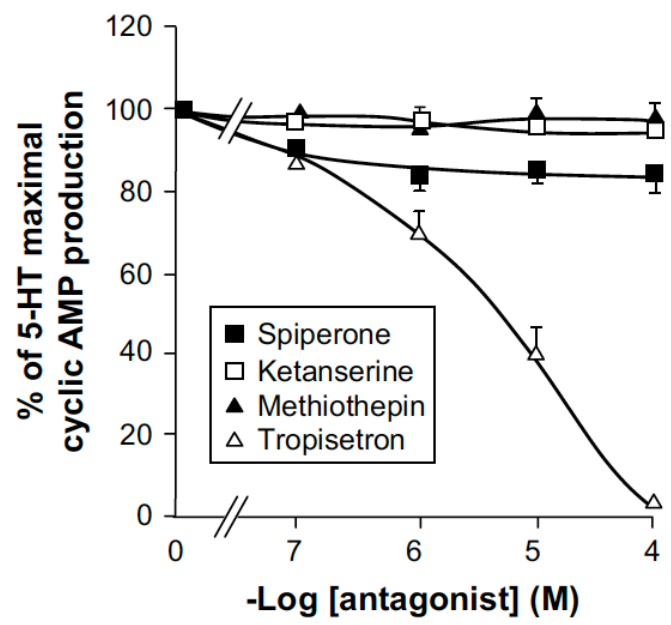

From Dumuis et al (1988) Molecular Pharmacology
B

Colliculi neurons in culture 1988

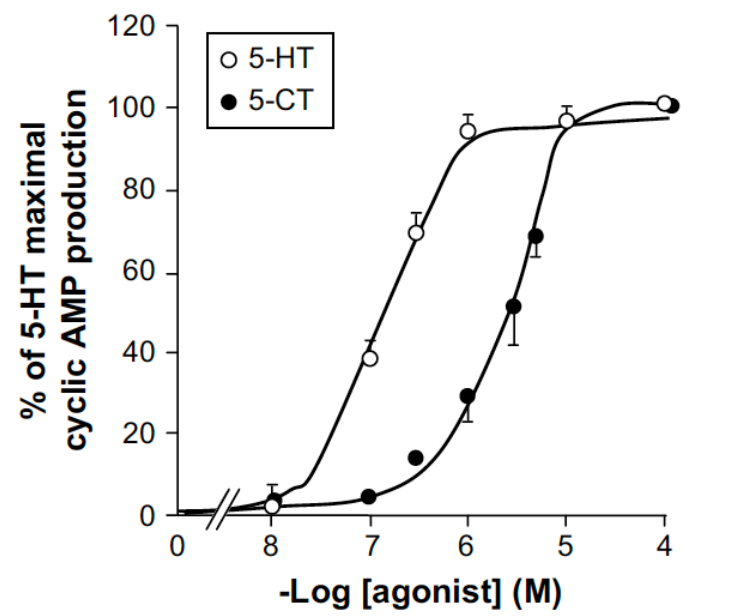

From Dumuis et al (1988) Molecular Pharmacology

D

Guinea-pig hippocampus (adult)

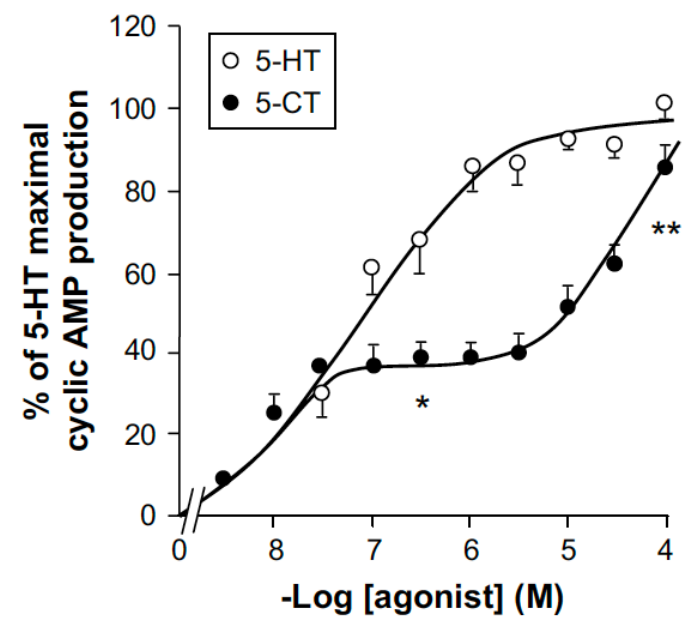

From Dumuis et al (1988) Molecular Pharmacology

E Guinea-pig hippocampus (adult)
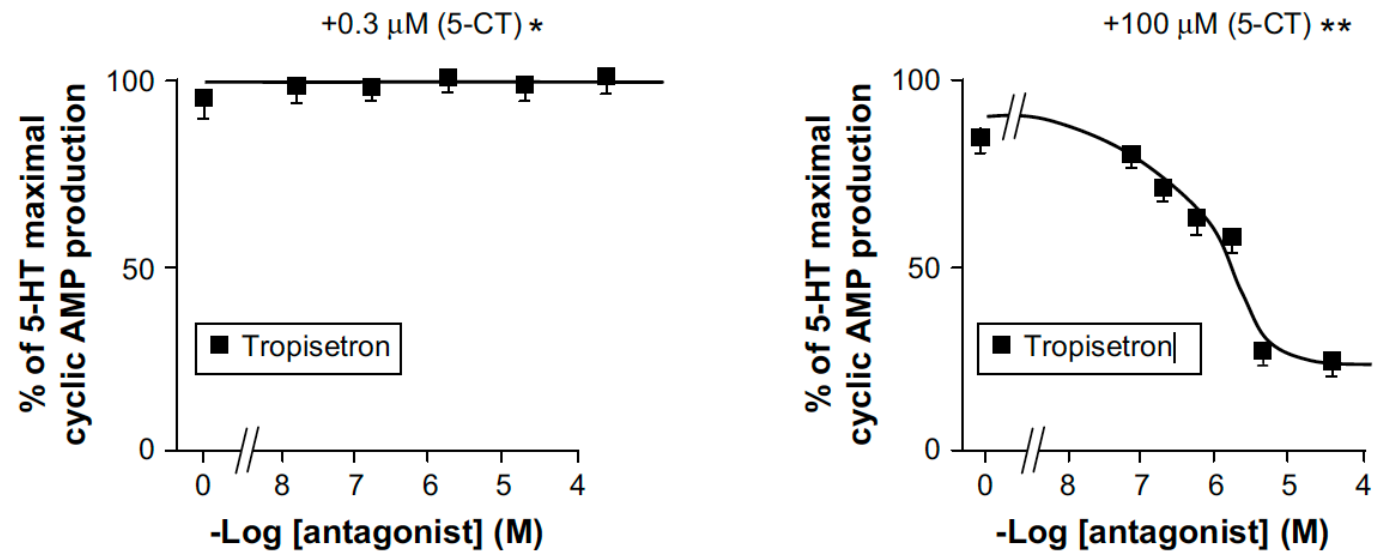

From Dumuis et al (1988) Molecular Pharmacology

Figure 1 

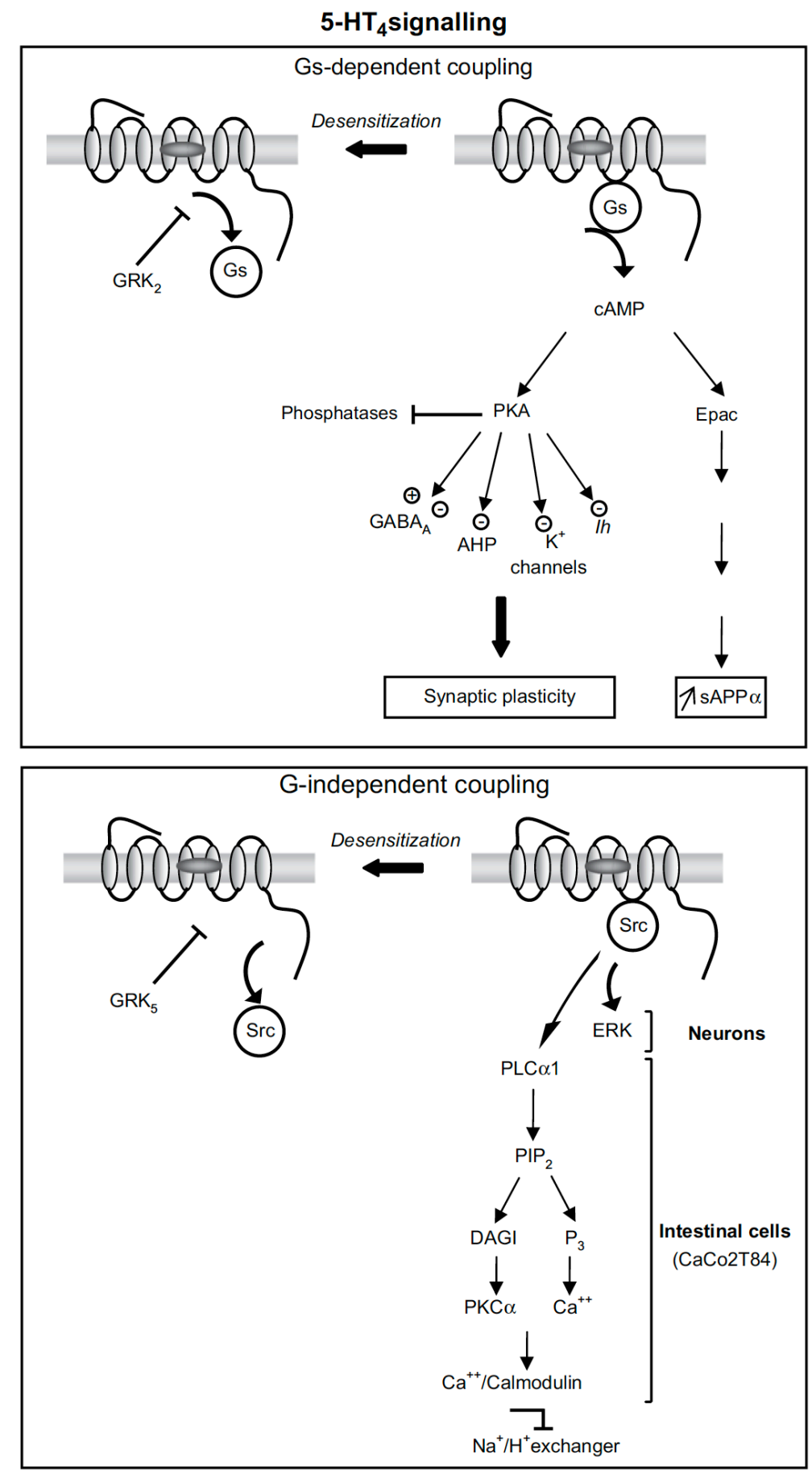

Figure 2 


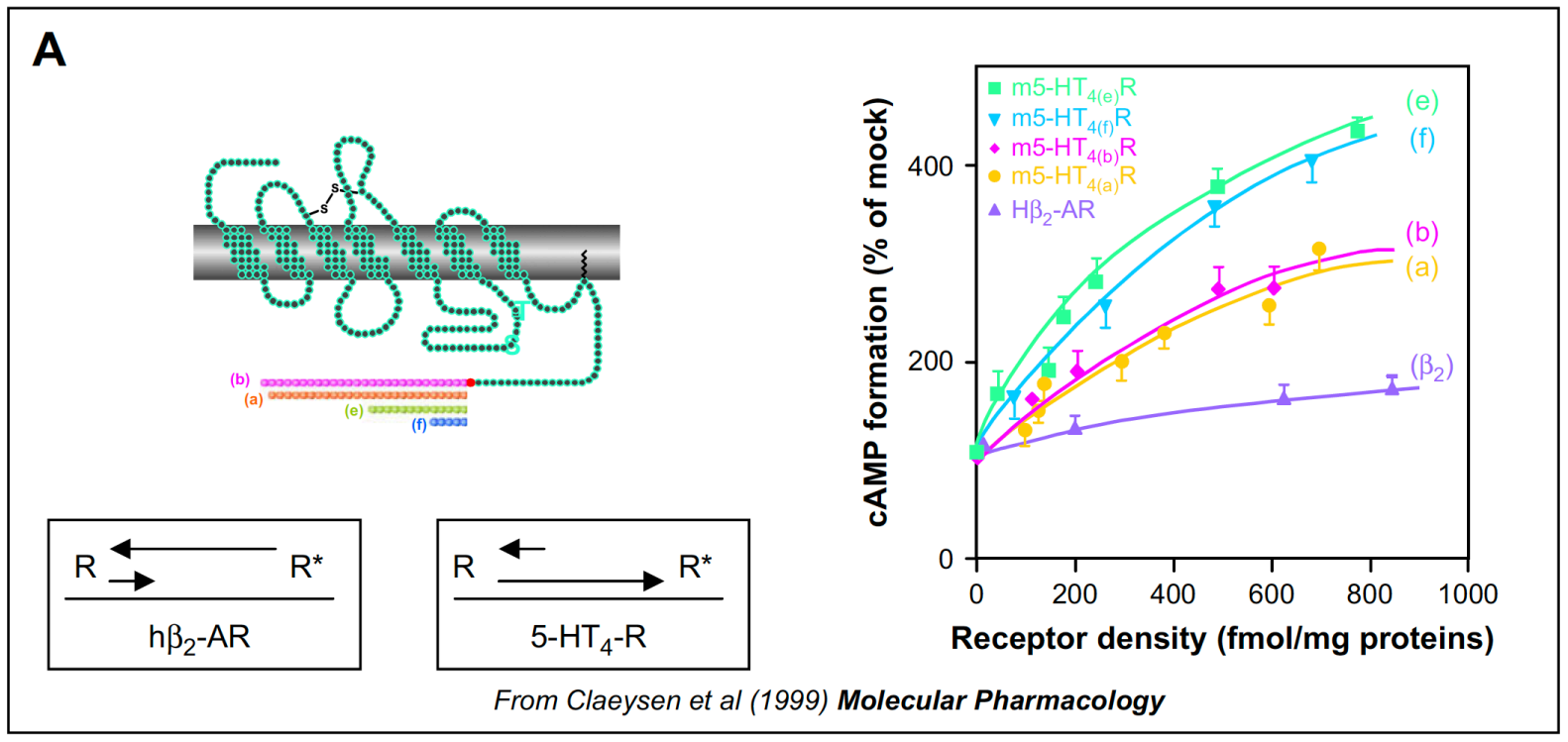

\begin{tabular}{|cc|}
\hline B & \multicolumn{2}{c|}{ Amine receptors } \\
T 3.36 & $1 \%$ \\
C 3.36 & $56 \%$ \\
S 3.36 & $31 \%$ \\
A 3.36 & $\beta_{2}$-AR \\
\hline
\end{tabular}

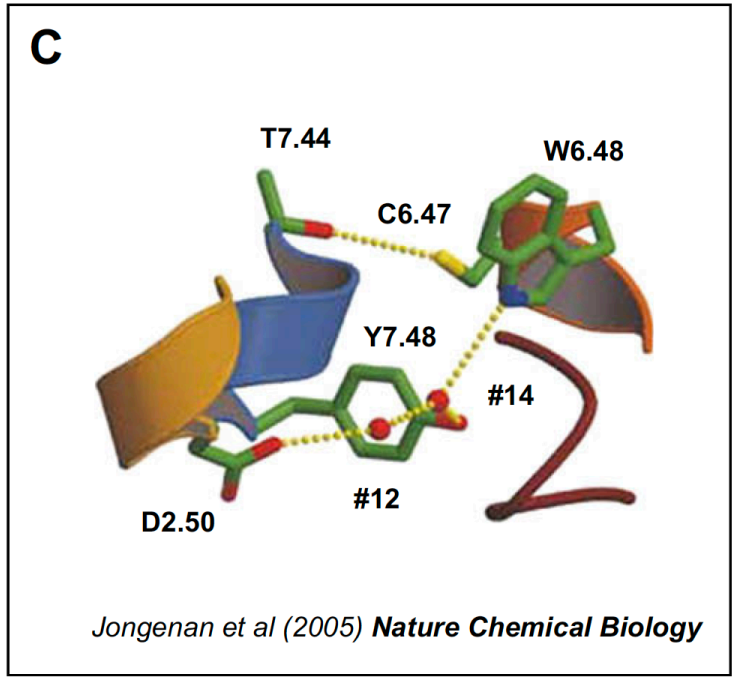

Figure 3 
A

Short-term olfactive memory
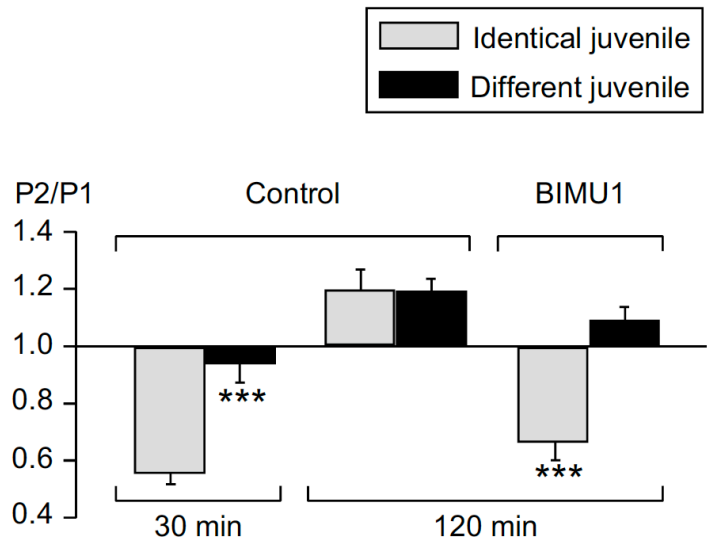

From Letty et al (1997) Neuropharmacology

C

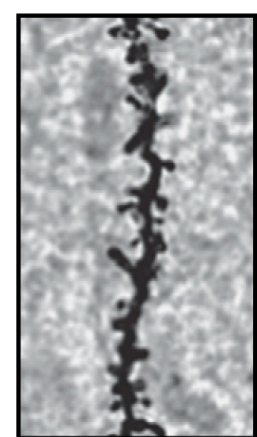

Trained + SL65.0155

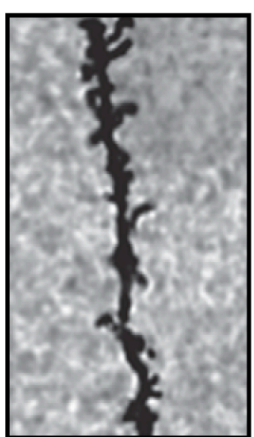

Trained+saline
B

Long-term associative memory
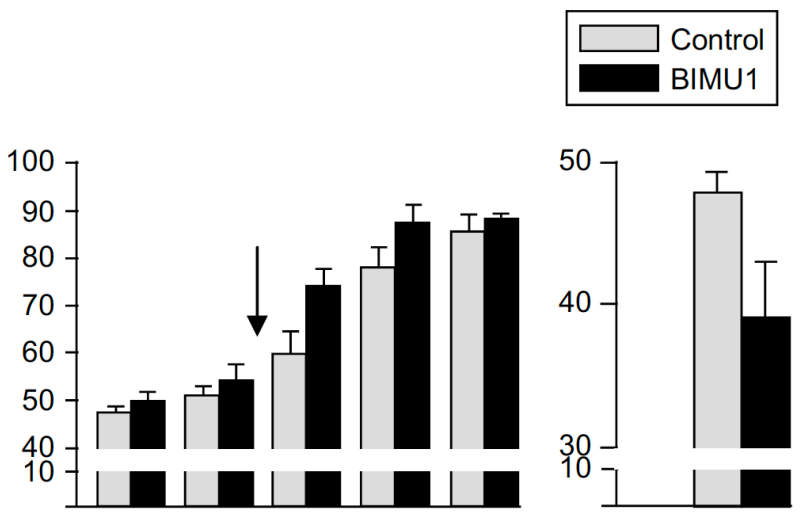

From Marchetti-Gauthier et al (1997) Neuropharmacology

From Restivo et al (2007) Neuropsychopharmacology

Figure 4 
A

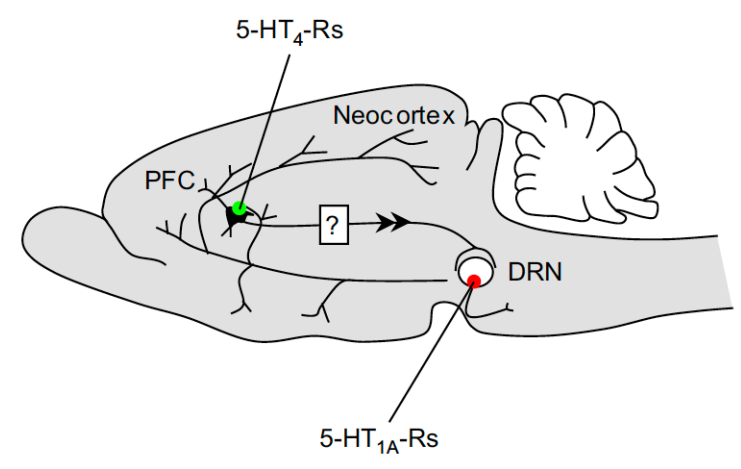

C

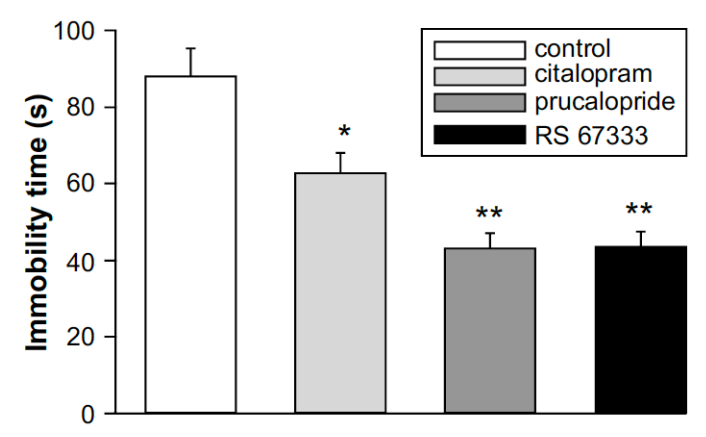

From Lucas et al (2007) Neuron
B
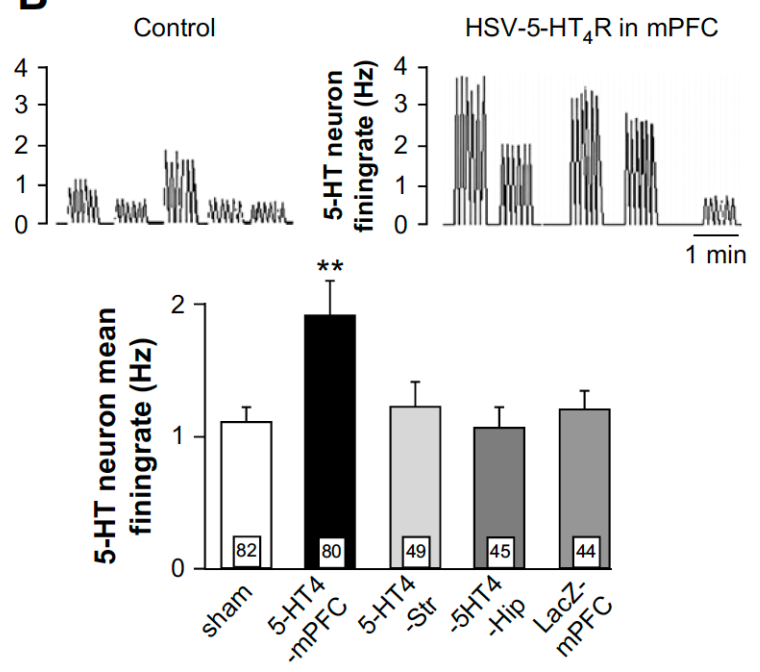

From Lucas et al (2005) Biology Psychiatry

D

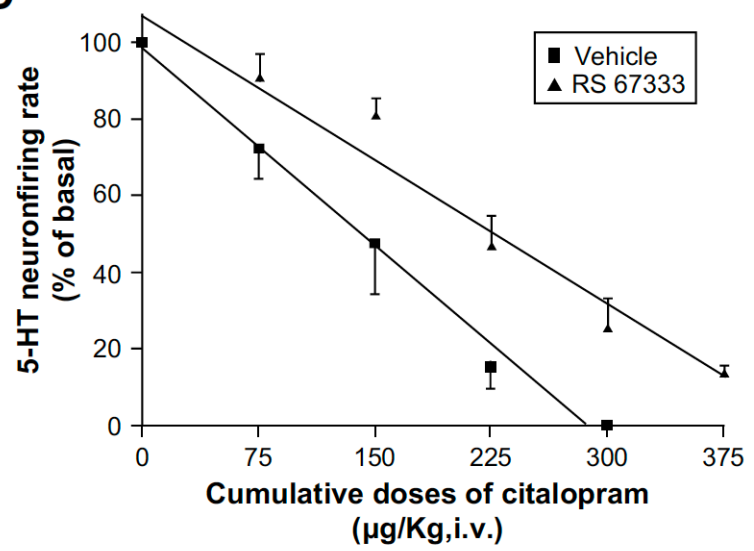

From Lucas et al (2007) Neuron

Figure 5 
A

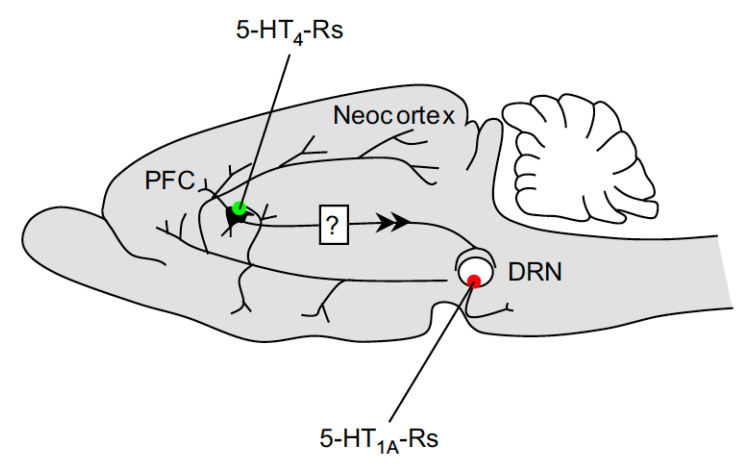

C

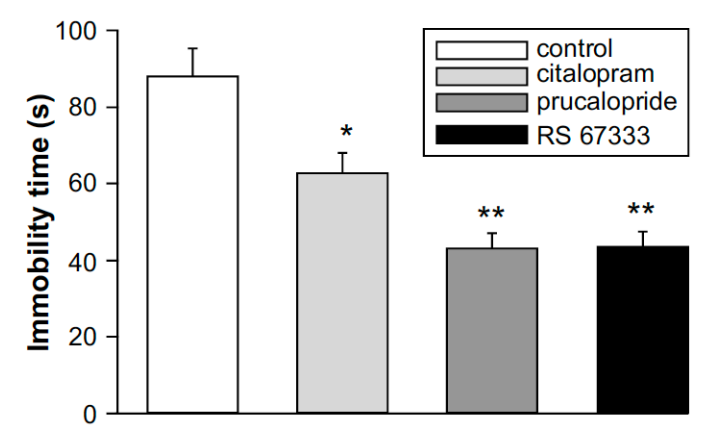

From Lucas et al (2007) Neuron
B
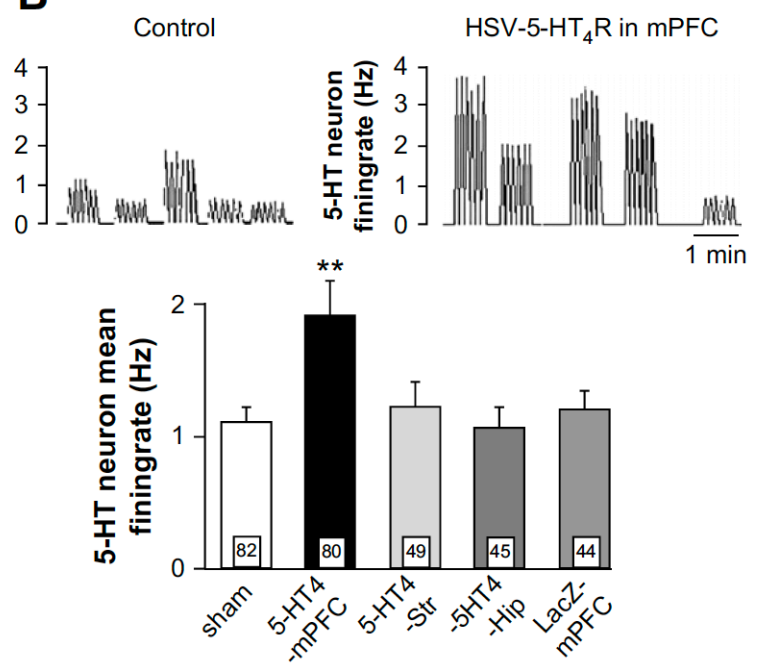

From Lucas et al (2005) Biology Psychiatry

D

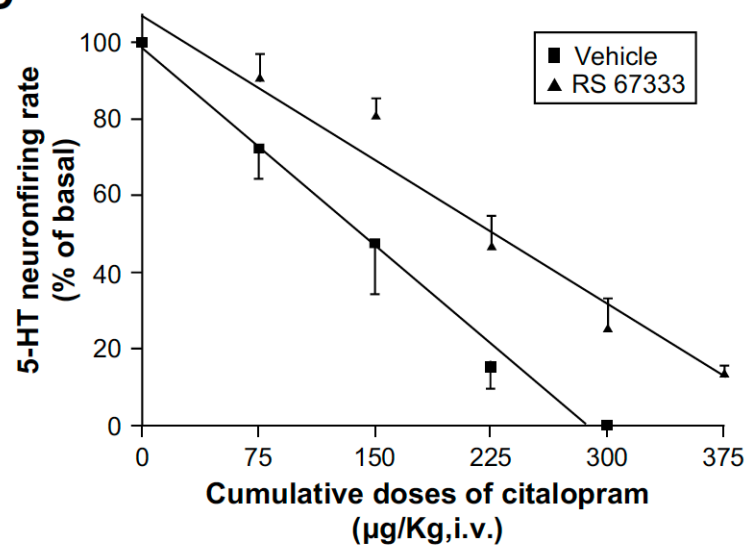

From Lucas et al (2007) Neuron

Figure 6 